\title{
The Glycemic Index and Organoleptic Test of Pekawai (Durio kutejensis) Chips
}

\author{
Lestari, $\mathbf{0}$. A. and *Purwayantie, $\mathbf{S}$. \\ Faculty of Agriculture, Tanjungpura University,Jl. A. Yani Pontianak, West Kalimantan 78124, Indonesia \\ Email: sulvipurwayanti06@gmail.com
}

Diterima 1 Oktober 2017/ Disetujui 10 November 2017

\begin{abstract}
Pekawai fruit (Durio kutejensis) is one of the durian species that grows wild in the forests of West Kalimantan. It is known by its yellow-golden orange flesh color. It does not have an unpleasant smell and has non sticky flesh, which makes it attractive and has potential to be healthy snacks such as fruit chips. This research was conducted to find out consumer preference by doing organoleptic and glicemic index test. The glycemic index test has been done by 10 volunteers and organoleptic test conducted using scoring and hedonic methods with 35 panelists. Data analyzed with descriptive method. The results showed that pekawai chips has low glycemic index (12) and were liked by the panelists. The results showed that pekawai fruit, the exotic local fruit from West Kalimantan has big potential to be developed as a snack, which has high economic value and safe to be consumed by diabetics.
\end{abstract}

Keywords: glycemic index, pekawai, fruit, chips

\section{INTRODUCTION}

There are 28-30 durian species in the world, where 20 species grows in Indonesia and 18 species found in Kalimantan. It has different names in different region. In West Kalimantan it is called pekawai, likul in South Kalimantan, pampaken in Central Kalimantan, and pulu in Brunei. Pekawai has unique characteristics. It has soft aroma, attractive yellow to golden orange flesh color, dried flesh texture, sweet taste and has ability long storage. This qualifications of this species gives potential to be developed for export (Santoso and Priyono, 2015). Another unique qualifications of pekawai based on the results of research conducted by Arung et al. (2015), it extracts contains antioxidants which can be used for skin lightening. Research about pekawai processed into chips using vacuum frying has been done by Purwayantie and Lestari (2016) which shows an increasing of nutrients value by more than $50 \%$. For further research it is important to do organoleptic test and measurement of glycemic index value prior to the further development of pekawai chips. Organoleptic test is important as the first step to measure the level of consumer acceptance before pekawai chips enter the market, while glycemic index value is needed as information for diabetics.

The glycemic index is a blood glucose response to the foods that containing carbohydrate on dose and time (Prijatmiko, 2007). The definition of glycemic index according to BPOM RI (2011) is the increasing rate of blood glucose levels after eating food that contains carbohydrates, the higher the GI, the higher the blood glucose levels. Information of glycemic index value is beneficial for patients with diabetes mellitus. According to The British Diabetics Association in Lestari (2009), diabetics are encouraged to consume at least $50 \%$ of the total intake of rice as foods that have a low glycemic index. The current data according to Ibrahim (2016), 20-22 million of the total population in Indonesia are diabetics, with 300-500 thousand of these diabetics are people from West Kalimantan.

Releated research for glycemix index measurement of many fruits was conducted by some researcher (Robert et al. 2008) but there are none which test the fruit chips effect on blood glucose level after consumption. Therefore, to developed the potential healthy pekawai chips as snack for diabetics, the results from this research will be very helpful for people in West Kalimantan. 


\section{MATERIALS AND METHODS}

\section{Materials}

The research begins with making chips from pekawai with vacuum frying process, the continued with organoleptic tests and measuirng glycemic index. The main ingredient we used was ripe pekawai fruit. The other materials are vegetable oil; pp plastic (polypropylene) and aluminum foil packaging. The tools are vacuum fryer with $2 \mathrm{~kg}$ capacity, $1.5 \mathrm{~kg}$ capacity spinner, glucometer from easy touch brands (GCU), and other tools needed for organoleptic test. This research conducted from January until April 2016. The vacuum frying process has been done in CV. Firjatul Jaya in Rasau Jaya III, Kubu Raya and the Laboratory of Agricultural Technology, Faculty of Agriculture, Tanjungpura University.

\section{Methods}

\section{a. Producing Pekawai Chips (Purwayantie and Lestari, 2016)}

Pekawai fruit skin and seeds are separated carefully so the fruit flesh is not damaged. The flesh is splitted into two parts and frozen for about 24 hours. Frozen pekawai fried using the vacuum fryer at $80-82^{\circ} \mathrm{C}$ and pressed $-76 \mathrm{cmHg}$, for 40 minutes. Fried pekawai chips then drained using spinner for 15 minutes, then packed in plastic foil before the next test.

\section{b. Organoleptic test (Adawiyah et al., 2007)}

Organoleptic test was carried out by 35 panelists using a scoring method on two samples of chips, the pekawai chips and commercial jackfruit chips. The purpose of this organoleptic test was to determine the level of acceptance of pekawai chips compared

with commercial jackfruit chips. Method used was scoring with scoring scale 1-5 (Table 1), preference level measured by hedonic scale from 1- 7, which score 1 was for strongly dislike, score 2 was for dislike, score 3 was for rather dislike, score 4 was for neutral, score 5 was for rather like, score 6 was for like, and score 7 was for strongly like.

Table 1. Organoleptic Attribute of Pekawai Chips Quality

\begin{tabular}{|c|c|c|c|c|c|}
\hline \multirow{2}{*}{$\begin{array}{c}\text { Quality } \\
\text { Attribute }\end{array}$} & \multicolumn{5}{|c|}{ Score } \\
\hline & 1 & 2 & 3 & 4 & 5 \\
\hline Color & $\begin{array}{l}\text { Not yellow } \\
\text { (another } \\
\text { yellow) }\end{array}$ & Light Yellow & yellow & Rather dark yellow & Dark yellow \\
\hline Aroma & $\begin{array}{l}\text { No Fruity } \\
\text { Aroma }\end{array}$ & $\begin{array}{l}\text { Weak Fruity } \\
\text { Aroma }\end{array}$ & $\begin{array}{l}\text { Proper Quantity } \\
\text { Fruity aroma }\end{array}$ & $\begin{array}{l}\text { Rather Strong } \\
\text { Fruity Aroma }\end{array}$ & $\begin{array}{c}\text { Strong Fruity } \\
\text { Aroma }\end{array}$ \\
\hline Texture & Not Crunchy & Rather Crunchy & Crunchy & Very Crunchy & $\begin{array}{l}\text { Strongly } \\
\text { Crunchy }\end{array}$ \\
\hline Taste & Plain & Less Sweet & Sweet & Very Sweet & $\begin{array}{l}\text { Strongly } \\
\text { Sweet }\end{array}$ \\
\hline
\end{tabular}

\section{c. Measurement of Glycemic Index (Lestari, 2009)}

The glycemic index was measured from 10 fasted respondents for at least 10 hours and then blood glucose levels being checked and taken. Then $50 \mathrm{~g}$ pure glucose was added to the samples in a glass of water $(200 \mathrm{ml})$. Blood glucose levels were checked again after 30 minutes, the next blood glucose levels measured again at intervals of 60, 90, and 120 minutes. The test was repeated seven days later with the pekawai chips samples containing $50 \mathrm{~g}$ of carbohydrate (carbohydrate levels of pekawai chips $69.65 \%$ ). The results of blood glucose measurement levels is shown in a graphic with time as abscissa (x) and blood glucose levels as ordinate (y). The glycemic index is determined based on comparison of the curve area between pekawai chips with pure glucose.

\section{d. Statistical Analysis}

The resulting data were tabulated and analyzed descriptively 


\section{RESULTS AND DISCUSSION}

\section{Glycemic Index Value}

The pattern of changes in blood sugar levels of glucose and pekawai chips for 2 hours from average respondents are shown in Figure 1 . The results of comprehensive comparison chart of pekawai chips to produce glucose in glycemic index value are low; 12 . Low glycemic index according to BPOM RI (2011) is less than 55. These results showed that pekawai chips are safe to be consumed for diabetics in terms of glycemic index.

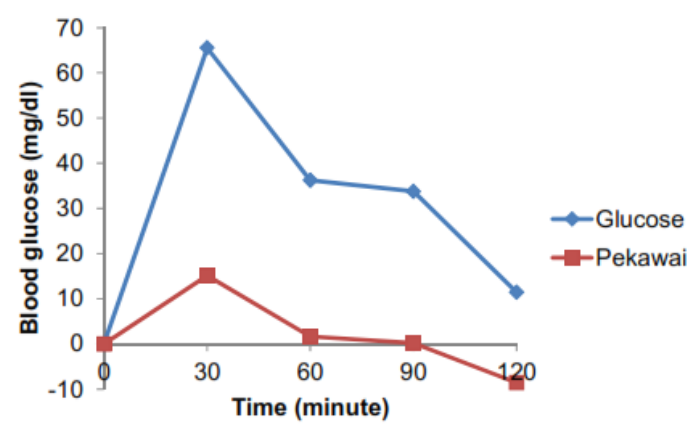

Figure 1. The Effect of Consumption of Pekawai Chips In Change of The System in Blood Glucose Levels Every 30 minutes fro 2 Hours

Glycemic index value from Malaysian durian reported by Robert et al. (2008), showed it has low glycemic index; 49 than any other fruit whic is melon 55 , papaya 58 and pineapple 82. Based on these researches, processing pekawai into chips can lower the glycemic index value. The decline in the value of the glycemic index may be due to increasing fiber and fat levels of the chips. Reported by Purwayantie and Lestari (2016) reported that the fiber increase up to 2 times $(5.55 \%$ to $11.20 \%)$ and the fat almost 4 times $(2.55 \%$ to $9.77 \%)$ from pekawai chips.

This is supported by Astawan and Wresdiyati (2004) statement, the higher the consumption of food that contains fiber (guar gum and pectin) can lower blood glucose. Durian and pekawai are a similar fruits (one species of Durio) which contained antioxidant and beta-carotene
(Charoensiri et al. 2009; Arung et al. 2015). Ketsa and Daengkanit (1999) reported that the levels of water soluble pectin and polygaracturonase and pectinesterase activity increased in ripe durian flesh than unripe durian. Both enzymes responsible for the pectin formation inside. Therefore, with similar chemical properties of the fruits, it is possible that pekawai chips also contained pectin. So that, the higher pectin level in chips increased the fibers. The other caused is due to the high fat content. According to Rimbawan and Siagian (2004), it slowing down the rate of gastric emptying process so the food digestion process in small the intestine will also slowing down and the release of glucose also slowing down.

\section{Organoleptic Test}

The results of organoleptic test showed that pekawai chips have similar quality to commercial jackfruit chips (Table 2). It is based on findings from the attribute of value quality of both fruit chips has the same level of preference (6 likes). There are unique properties of pekawai chips from the findings based on the attributes of organoleptic test (color and aroma).

Table 2. The Result of Scoring and Hedonic Test from Pekawai Chips and Commercial Jackfruit Chips

\begin{tabular}{ccccc}
\hline Quality & \multicolumn{2}{c}{ Pekawai Chips } & \multicolumn{2}{c}{ Commercial } \\
Attribu & \multicolumn{3}{c}{ Jackfruit Chips } \\
\cline { 2 - 5 } te & $\begin{array}{c}\text { Scor } \\
\text { e }\end{array}$ & $\begin{array}{c}\text { Descripti } \\
\text { on }\end{array}$ & $\begin{array}{c}\text { Scor } \\
\text { e }\end{array}$ & $\begin{array}{c}\text { Dscripti } \\
\text { on }\end{array}$ \\
\hline Color & 4 & Dark & 3 & Yellow \\
Aroma & 3 & Yellow & 2 & Weak \\
Textur & 3 & Fruity & 3 & Fruity \\
e & 3 & Aroma & 3 & Aroma \\
Taste & 6 & Crunchy & 6 & Crunchy \\
Hedoni & & Sweet & & Sweet \\
Like & & Like \\
c & & Like
\end{tabular}

Descriptively, pekawai chips have a dark yellow and strong aroma compared to jackfruit chips. Other study states that pekawai has a yellow until orange gold color which is more attractive compared to the other durian species that have yellow light, which becaused of its beta-carotene (Charoensiri et al., 2009). The smell of durian from Indonesia based on the 
research by Jiang et al. (1998), contain four main ccomponents, they are; 1, 1diethoxyethane, ethyl 2-methylbutanoate, ethyl (Z) -4-decenoate and acetoin.

The texture (crunchiness) and taste (sweetness) quality of both chips are same. Pekawai chips crunchy texture is caused by lower levels of water content. The study conducted by Sipahutar (2008), showed that the lower the levels of water content in fruit chips, the crunchier the products. The sweetness taste of pekawai fruit is the natural sweetness from ripe fruit, without sweeteners added. Other researchs show that the amount of sugar from pekawai ranged from 11.7 to $18.95 \%$ are higher than other durian species (2.10 to $14.5 \%$ ). So that the pekawai chips taste based on organoleptic test is sweeter (Belqis et al., 2016). The sweet taste of durian will be more increase due to it ripeness level cused by the highest of sucrose followed by glucose, fructose and maltose (Belgis et al., 2016). Shaffiq et al. (2013) explained too that Durio kutejensis have higher value of sucrose` $13 \%$.

\section{Conclusion}

This is the first report of glycemic index test out of fruit chips in Indonesia. The results of the research showed that the pekawai chips have low glycemic index value; 12. Consumer preference is 6 (Like). The advantage of pekawai chips are it has high value of consumer preference and low blood glucose so it has potential to be developed as snack for diabetics. Further studies are needed to determine pectin, amilosa, amilopectin and sugar profile with HPLC of pekawai flesh to support the chemicals of fiber from Durio kutejensis which has potential to become a healthy chips.

\section{References}

Adawiyah DR, Waysima and Indrasti D. 2007. Guidance of Sensory Evaluation Practice. Faculty of Agricultural Technology, Institut Pertanian Bogor, Indonesia

Arung ET, Suwinarti W, Hendra M, Supomo, Irawan WK, Putri DCN, Eroglu HA, Kim Y, Shimizu K and Ishikawa $\mathrm{H}$.
2015. Determination of antioxidant and antimelanogenesis activities of indonesia lai, Durio kutejensis [Bombacaceae (Hassk Becc)] fruit extract. Tropical Journal of Pharmaceutical Research 14(1): 41-46.

Astawan M and Wresdiyati. 2004. Healthy Diet with Fiber Foods. Tiga Serangkai, Solo, Indonesia.

Belgis $\mathrm{M}$, Wijaya $\mathrm{CH}$, Apriyantono $\mathrm{A}$, Kusbiantoro $B$ and Yuliana ND. 2016. Physicochemical differences and sensory profiling of siz lai (durio kutejensis) and four durian (Durio zibethinus) cultivars indigenous indonesia. International Food Research Journal 23(4): 1466-1473.

BPOM RI. 2011. The National Agency of Drug and Food Control. NO. HK.03.1.23.11.1.09909 Tahun 2011 about Supervision Claims in The Labeling and Advertising of Processed Food.

Charoensiri R, Kongkachuichai R, Suknicom S. and Sungpuuag P. 2009. Betacarotene, lycopene and alphatocopherol contents of selected thai fruits. Food Chemistry 113: 202-207.

Ibrahim N. 2016. IDI: 300-500 Thousand of Peoples in West Kalimantan Suffer from Diabetic. Retrived on April 1, 2016 from Website: http://thetanjungpuratimes.com/2 016/04/16/idi-300-500-ribuwarga-kalbar-menderita-diabetes/

Ketsa S and Daengkanit T. 1999. Firmness and activities of polygalacturonase, pectinesterase -galactosidase and cellulose in ripening durian harvested at different stages of maturity. Scinetia Horticulturae 80: 181188. 
Lestari OA. 2009. Characterization of physicochemical and evaluation nutritional biological values of dried corn noodles subtituted with modified corn starches. Bogor, Indonesia: Agricultural Institute of Bogor, MSc thesis.

Prijatmiko D. 2007. The glicemix index from one hour postprandial staple food, rice, corn and potato. Cermin Dunia Kedokteran 34: 285-288.

Purwayantie S. and Lestari OA. 2016. Pekawai fruit chips nutritional potentional, the exotic fruits from west kalimantan. In Zain Z, Bariyah N, and Astiani D. (Eds). Proceeding of National Seminar on Science and Technology Application, p. 379-383. Pontianak: Tanjungpura University, West Kalimantan, Indonesia

Rimbawan. and Siagian A. 2004. Glicemix Index of Food. Jakarta: Penebar Swadaya.
Robert DA, Ismail A, Winn T, Thomas and Wolever. 2008. glycemic index of common malaysian fruits. Asian Pacific Journal of Clinical Nutrition 17(1): 35-39.

Santoso PJ, and Priyono A. 2015. The potential and status development of the three durian family: lai, mandong, and keratungan. Iptek Hortikultura 11: 31-37.

Shaffiq SMA, Sidik BJ, Harah ZM, and Devi RS. 2013. Marketable wild fruits of sarawak, borneo: their mode of consumption, uses and sugar profiles. Indian Journal of Traditional Knowledge 12: 195201.

Sipahutar SR. 2008. Humectant Concentration Effect and Storage Time on Durian Seed (Durio zibethinus Murr) Chips. Departement of Agricultural Technology, USU Repository, Indonesia 